\title{
VPLIV PROGRAMOV PREDPRISTOPNE POMOČI EU NA RAZVOJ OBMEJNIH OBMOČIJ SLOVENIJE V OBDOBJU I994 - 2004
}

\author{
Ivo Piry \\ Služba Vlade RS za lokalno samoupravo in regionalno politiko \\ Kotnikova 28, 1000 Ljubljana \\ e-mail: ivo.piry@gov.si
}

Pregledni znanstveni članek

COBISS 1.02

\section{Izvleček}

Prispevek prikazuje nekatere elemente razvoja obmejnih območij Slovenije predvsem z vidika učinkov pred pristopne pomoči programa Phare čezmejnega sodelovanja (v nadaljevanju Phare $\mathrm{CBC}$ ). Regionalni razvoj obmejnih območij Slovenije je v vsej svoji dosedanji zgodovini tesno povezan z geopolitičnim položajem in funkcijo obmejnih območij. Republika Slovenija je od leta 1992 prejemala pomoč Evropske unije iz programa Phare. Po letu 1994 je bila vključena tudi v posebni predpristopni program EU Phare CBC.

Ključne besede: regionalni razvoj, obmejna območja, predpristopna pomoč EU, programi Phare

\section{INFLUENCE OF EU PRE-ACCESSION PROGRAMMES ON REGIONAL DEVELOPMENT OF BORDER AREAS OF SLOVENIA IN PERIOD 1994-2004}

\begin{abstract}
Article reviews some elements of development process if border areas of Slovenia as regards influences of pre-accession programme Phare cross-border co-operation (Phare CBC). Republic of Slovenia received Phare assistance from 1992 onwards. Regional development of slovene border areas was closely related to the geopolitical situation and function of border areas. After 1994 it was included also in the programme of cross border co-operation Phare $\mathrm{CBC}$. It was aimed at fighting regional differences of border areas that were neglected as regards investments and remained most peripheral areas of the country.
\end{abstract}

Key words: regional development, border areas, EU pre-accession programmes, Phare programmes 


\section{UVOD}

Namen prispevka je prikazati nekatere elemente razvoja obmejnih območij Slovenije kot se kažejo z vidika učinkov pred pristopne pomoči programa Phare čezmejnega sodelovanja (v nadaljevanju Phare CBC). Republika Slovenija je od leta 1992 prejemala pomoč Evropske unije iz programa Phare. Po letu 1994 je bila vključena tudi v posebni predpristopni program EU Phare CBC z območjem ob slovensko-italijanski državni meji, v letu 1995 po tudi z območjem ob slovensko-avstrijski državni meji, ko je Avstrija postala polnopravna članica EU. Čezmejni programi so se v letu 1996 razširili tudi na Pomurje s posebnim trilateralnim programom med Avstrijo, Slovenijo in Madžarsko. Že leta 2000 pa je Slovenija sprejela v sodelovanju s sosednjimi državami Italijo, Avstrijo in Madžarsko strateške razvojne dokumente za sodelovanje v programu Phare CBC. Pod naslovom Skupni programski dokument INTERREG III A/Phare CBC za obdobje 2000-2006 so bili ločeno pripravljeni trije dokumenti, po eden za posamezno obmejno območje ob državni meji z Italijo, za obmejno območje ob državni meji z Avstrijo in za obmejno območje od slovensko madžarski državni meji.

Regionalni razvoj obmejnih območij Slovenije je v vsej svoji dosedanji zgodovini tesno povezan z geopolitičnim položajem in funkcijo obmejnih območij, ki se ni kazala samo v spreminjanju poteka mejne linije ter s tem povezanim prehajanjem posameznih delov obmejnih območij pod vpliv različnih političnih in gospodarskih sistemov, temveč tudi v spreminjanju funkcije državne meje, ki v zadnjih desetletjih preteklega stoletja vse bolj postaja povezovalni člen med sosednjimi državami. Raziskava M. Bufona (Bufon 1995) na italijanski strani državne meje, ki je ugotavljala stopnjo in procese socio-ekonomskega razvoja obmejnega območja, ki je bilo v pogojih tržnega gospodarstva in skupnega EU trga že tedaj upravičeno do uporabe tedanjih instrumentov regionalne pomoči/strukturne politike EU, je bila ena prvih, ki se je ukvarjala tudi s programi EU.

\section{OPREDELITEV OBMOČJA}

Opredelitev obmejnih območij se je v Sloveniji v zadnjem desetletju prilagajala spreminjajočim se okoliščinam in predvsem kriterijem, ki jih je uveljavljala EU pri izvajanju programov predpristopne pomoči Phare CBC. Oblikovanje obmejnih območij je pogosto sledilo tudi interesom, ki so predvsem na ravni lokalnih skupnosti izražali željo po formalni vključitvi v obmejno območje.

V obdobju med letoma 1991 in 1999 se je pri teritorialni opredelitvi obmejnih območij z Italijo in Avstrijo praviloma uporabljala nekdanja opredelitev maloobmejnega območja, ki je zajemal 10-kilometrski pas ozemlja ob državni meji. Opredelitev je temeljila na nekdanjih sporazumih o maloobmejnem prometu, ki jih je nekdanja Jugoslavija podpisala z Italijo in Avstrijo. Z uveljavitvijo reforme lokalne samouprave v letu 1995 se je opredelitev območja naslonila na nove občinske meje tako, da so bile vključene vse občine, ki so imele vsaj polovico ozemlja v statusu nekdanjega obmejnega območja. Opredelitev obmejnega območja je bila le 
posredno potrjena v okviru sprejemanja Finančnih memorandumov za izvajanje Phare CBC programov za posamezna obmejna območja, nikoli pa ni doživela posebne določitve v vladnih dokumentih. S sprejemom nove regulative EU za področje izvajanja Phare CBC programov v letu 1998, so bili ti glede teritorialnega pristopa izenačeni s kriteriji, ki se uporabljajo za evropsko iniciativo INTERREG, v okviru katere se območja izvajanja teh programov določajo na ravni statističnih regij (NUTS III). Zato so bila obmejna območja v novih programskih dokumentih določena na ravni statističnih regij in vključujejo v obmejnem območju z Italijo Obalno-kraško in Goriško regijo ter občino Kranjska gora, v obmejnem območju z Avstrijo Gorenjsko, Savinjsko, Koroško, Podravsko in Pomursko regijo ter v obmejnem območju z Madžarsko Pomursko statistično regijo. Odprto ostaja vprašanje Osrednjeslovenske regije, ki se s svojim teritorijem ne dotika državne meje, vendar se v pogajalskem procesu predstavlja tudi kot regija, ki se bo vključevala v program INTERREG (Piry 2004)

\section{REGIONALNE RAZLIKE}

Razvojne razlike posameznih regij v Sloveniji niso nov pojav in gospodarska politika se je s temi problemi ukvarjala, še preden je leta 1991 Slovenija postala neodvisna. Že v sedemdesetih letih je Slovenija začela spodbujati bolj uravnotežen regionalni razvoj na podlagi koncepta policentričnega razvoja. Na podlagi tega koncepta so bili sprejeti različni ukrepi, katerih skupni imenovalec je bil zmanjševanje razlik med regijami, kar zadeva delovne in življenjske razmere. Kljub nekaterim pozitivnim rezultatom, ki jih je dal bolj uravnoteženi regionalni razvoj v Sloveniji v obdobju pred letom 1990 (infrastruktura se je izboljšala, struktura gospodarstva je postala bolj raznolika, zaposlovanje je naraščalo), so se povečali tudi problemi. Delovnih mest za visoko izobraženo delovno silo ni bilo dovolj, zato so mladi po končanem šolanju odhajali na druga področja. Da bi se lotili problema zmanjševanja populacije, zlasti na oddaljenih in v goratih območjih, je bil sprejet zakon o zaščiti demografsko ogroženih območij. Ker se je obseg sredstev, namenjenih za to področje, vseskozi zmanjševal, t.j. od 0,25 odstotka BDP leta 1991 na 0,04 odstotka BDP leta 1997 (oziroma na 0,08 odstotka, če upoštevamo tudi posojila Sklada za regionalni razvoj in ohranjanje podeželja), so bili rezultati razmeroma skromni.

Kar zadeva demografske značilnosti so se le-te poslabšale v večjem delu Slovenije. V zadnjih letih se je rodnost zmanjševala, življenjska doba pa zviševala, kar je povzročilo močno staranje populacije. Indeks staranja populacije po vsej Sloveniji je leta 1998 znašal 80 (v primerjavi s 50 leta 1981), značilne pa so zelo velike razlike med regijami, saj vrednosti segajo od 65 za Dolenjsko in Koroško do 99 za Obalno-kraško regijo. Na občinski ravni so razlike še večje in znašajo od pičlih $50 \mathrm{v}$ nekaterih novih industrijskih mestih pa do več kot $150 \mathrm{v}$ oddaljenih podeželskih regijah.

Poleg tega obstajajo tudi velike razlike v gostoti prebivalstva. Nekako 75 odstotkov vsega prebivalstvaje zgoščeno na približno 1/3 državnega ozemlja; tu se gostota poseljenosti še povečuje in znaša okoli 216 oseb/km2. Območja s stagnirajočo populacijo obsegajo 26 odstotkov ozemlja in 12 odstotkov prebivalstva s povprečno gostoto $45 \mathrm{ljudi} / \mathrm{km}^{2}$. Območja z veliko depopulacijo predstavljajo največji delež ozemlja države - 41 odstotkov - in 13 odstotkov prebivalstva, 
s katerimi povprečna gostota na teh območjih znaša 31 ljudi $/ \mathrm{km}^{2}$. Največja depopulacijska območja so kmetijska in periferna območja s šibko ekonomsko strukturo, zlasti območja vzdolž meje s Hrvaško, Madžarsko in Italijo, in vključujejo Pomursko, Posavsko, Goriško in Kraško regijo. Glavni vzroki za tolikšno depopulacijo so bili nizka rodnost, pomanjkanje delovnih mest in odseljevanje.

V obdobju tranzicije so se razlike v razvitosti regij povečale. Pomembne so zlasti razlike v demografskih pogojih, človeškem kapitalu, gospodarski strukturi in uspešnosti gospodarjenja, opremljenosti z družbeno in gospodarsko infrastrukturo, obsegu okoljskih problemov in notranji homogenosti (delež občin $\mathrm{v}$ regiji s statusom območja s posebnimi razvojnimi problemi). Povečevanje regionalnih razlik je pogosto posledica neizkoriščenosti endogenih razvojnih potencialov regij.

V prvih letih po osamosvojitvi je prišlo do velike centralizacije sredstev in odločanja na ravni države, ker so bile v ospredju naloge oblikovanja politične in upravne strukture države. Regionalni razvoj je bil potisnjen v ozadje, delež sredstev za regionalne razvojne spodbude v bruto domačem proizvodu se je iz leta v leto zmanjševal. Prehod v tržno gospodarstvo je različno vplival na položaj posameznih regij. Sprememba ekonomskega sistema, privatizacija, globalizacija in razvoj postindustrijske družbe so najbolj prizadeli velika podjetja slovenske industrije, nasprotno pa so politične spremembe ugodno vplivale na rast malih podjetij in na rast storitev državne uprave in finančnega sektorja. Zaradi različne izhodiščne gospodarske strukture so bile regije različno prizadete (poslabšanje relativnega položaja podravske, zasavske in koroške regije, izboljšanje relativnega položaja osrednje slovenske, obalno kraške, goriške in dolenjske regije).

Če primerjamo razvitost Slovenije z državami članicami EUv času, koje pričela prejemati predpristopno pomoč (ocena za obdobje 1995-1997), je bila po bruto domačem proizvodu na prebivalca po kupni moči ${ }^{1}$ Slovenija s $66 \%$ povprečja petnajsterice na ravni razvitosti najslabše razvite države članice Grčije (v letu 1998 je Slovenija dosegla 68 \% povprečja EU). Po oceni je dosegla Ljubljanska urbana regija tedaj 87 \% povprečja petnajsterice. Primerjava z nam najbližjimi regijami držav članic v Avstriji in Italiji na ravni NUTS 2 pokaže, da je Ljubljanska urbana regija le nekoliko manj razvita od Južne Avstrije, kjer dosega Koroška 89 \%, Štajerska pa 90 \% povprečja razvitosti EU. Bistveno večji je zaostanek za vzhodnim delom severne Italije, saj regija Furlanija Julijska Krajina presega povprečje petnajsterice za kar 27 \%. Precej večje medregionalne razlike so znotraj Slovenije na nižji teritorialni ravni - med statističnimi regijami, še bolj pa med občinami, čeprav bi glede na samo velikost Slovenije pričakovali manjše razlike. Razmerje med regijama z najvišjo (Osrednjeslovenska) in najnižjo (Pomurska) vrednostjo kazalca je leta 1999 znašalo 1,9:1 in je na bolj ali manj enaki ravni že nekaj let.

\footnotetext{
${ }^{1}$ SURS je v letu 1999 prvič objavil podatke o bruto domačem proizvodu na prebivalca po 12 statističnih regijah (pred sprejetjem SKTE) za leto 1996, v letu 2000 pa še za leto 1997. Podatki za obdobje 1995-1997 so ocena Eurostata. na osnovi podatkov SURS-a iz leta 1996. Razdelitev po SKTE pa je ocena ZMAR-a.
} 
Ob osamosvojitvi Slovenije se je regionalna politika s sprejemom zakona o spodbujanju razvoja demografsko ogroženih območij osredotočila predvsem na ohranjanje poseljenosti vseh predelov slovenskega ozemlja. Že leta 1994 je Vlada RS pripravila nov predlog zakona o spodbujanju skladnejšega regionalnega razvoja, ki zaradi številnih sistemskih sprememb, $\mathrm{s}$ katerimi je bil povezan predlog zakona, kot je bilo uvajanje lokalne samouprave in reforma državne uprave, ni doživel prve obravnave v državnem zboru vse do leta 1996. Od takrat so se okrepile dejavnosti Slovenije pri njenem vključevanju v Evropsko unijo, kar je prineslo vrsto novih zahtev in potreb glede prilagoditve naše pravne ureditve spodbujanja razvoja $\mathrm{v}$ skladu s pravili Evropske unije, kjer sta ureditev regionalne ravni načrtovanja in okrepitev medsektorskega usklajevanja med najpomembnejšimi nalogami spodbujanja skladnega regionalnega razvoja $\mathrm{v}$ okviru strukturne in kohezijske politike Evropske zveze. Zato je bilo potrebno pripraviti enoten in učinkovit koncept vodenja politike regionalnega razvoja in zagotoviti učinkovito medresorsko usklajevanje razvojnih programov, ob sodelovanju in iniciativi lokalnih skupnosti.

\section{PREDPRISTOPNA POMOČ OBMEJNIM OBMOČJEM}

S programom Phare čezmejnega sodelovanja v Sloveniji je bilo omogočeno uresničevanje različnih ciljev. Na prvem mestu je bilo zagotavljanje socialne in ekonomske kohezije obmejnih območij, ki bi omogočila zmanjševanje razlik v gospodarski razvitosti na obeh straneh sedanje državne meje in njihovo komplementarno razvojno dinamiko. Drugi cilj je bil pridobivanje potrebnih izkušenj in ustvarjanje pogojev za črpanje sredstev iz Strukturnih skladov EU po vključitvi med polnopravne članice EU. Predpristopni instrumenti so pomenili poleg pomembnega finančnega vira namenjenega razvojnim projektom, hkrati tudi edinstveno priložnost za seznanitev z načini in postopki priprave in izvajanja projektov, kot to zahteva regulativa za področje strukturne politike EU. Regionalna politika se v EU namreč uresničuje preko politike strukturnih skladov, kohezijske politike in politike konkurenčnosti v okviru notranjega trga EU.

Program čezmejnega sodelovanja je bil eden od programov PHARE, katerega finančna linija je bila odprta z namenom vzpodbujanja in podpore regionalnemu razvoju in sodelovanju ob meji. Za Slovenijo je bil ta program izrednega pomena, med drugim tudi zato, ker je šlo $\mathrm{v}$ tem primeru za naložbena sredstva, medtem ko so ostali programi PHARE bili orientirani predvsem v tehnično pomoč in usposabljanje administrativne usposobljenosti za izvajanje različnih ukrepov strukturne politike EU. Poleg tega je bil Program čezmejnega sodelovanja zelo pomemben za nas tudi zato, ker je bil usmerjen na obmejna območja, ki so bila $\mathrm{V}$ preteklosti zaradi perifernega položaja manj zanimiva za gospodarske investicije oz. se vanje ni vlagalo, saj je meja nekoč pomenila bolj oviro, kot možnost medsebojnega sodelovanja.

Osnovno načelo pri črpanju sredstev predpristopne pomoči je temeljilo na programiranem usmerjanju sredstev. Sredstev iz strukturnih skladov ni mogoče pridobiti za posamezne nepovezane investicije. Podlaga za sofinanciranje je zahtevana v obliki regionalnih razvojnih programov in programskih dokumentov, iz katerih nato izhajajo posamezni projekti. Slovenija je skupaj z regijama Furlanijo Julijsko krajino in Venetom tako sodelovala že pri pripravi 
Večletnega indikativnega programa za Phare program čezmejnega sodelovanja v obdobju 1994-1999. Sodelovanje se je še okrepilo s sprejemom Skupnega programskega dokumenta za obdobje 2000-2006, ki je povezoval program Phare čezmejnega sodelovanja do njegovega izteka v letu 2004 z iniciativo INTERREG IIIA ter predstavljal usklajeno strateško podlago za izvajanje projektov v okviru dogovorjenih prioritet, na temelju skupnega institucionalnega okvira, ki upošteva načelo enakopravnosti.

Čeprav so meje med Slovenijo, Italijo, Avstrijo in Madžarsko dokaj odprte in so že do sedaj omogočale razvoj neposrednih stikov, pa je še vedno veliko ovir, ki otežujejo sodelovanje. Med pomembnejšimi ovirami so, neustrezne prometne povezave, zlasti lokalnega cestnega omrežja, ozka grla na glavnih mejnih prehodih in neenakomernost poselitve na posameznih območjih, depopulacijski trendi in odseljevanje mladih, nizka izobrazbena struktura in pomanjkanje specifičnih znanj, velika odvisnost od tradicionalnih industrij in pomanjkanje podjetniške klime, visoka stopnja brezposelnosti, problem majhnosti in razdrobljenosti, pomanjkanje informacij, znanja in organizacijskih struktur.

S pomočjo programa Phare za čezmejno sodelovanje je Slovenija po letu 1995 pričela z uresničevanjem načela partnerstva $v$ načrtovanju in izvajanju regionalnega razvoja. Izvajanje programa Phare CBC je zajemalo vsa ključna razvojna področja, ki so vitalnega pomena za razvoj lokalnih skupnosti kot tudi za usklajen razvoj države Slovenije. S programom Phare za čezmejno sodelovanje so bili vzpostavljeni mehanizmi, s katerimi je bilo mogoče

a) aktivirati in podpreti integrirani razvoj, da bi dosegli trajno gospodarsko rast in s tem

b) promovirati regijo $\mathrm{v}$ nacionalnem in mednarodnem okviru in spodbujati najbolj celovito rabo njenih domačih virov in sposobnosti za podjetništvo njenih prebivalcev.

Splošni razvojni trendi in izkušnje mnogih držav in regij dokazujejo, da je za ustvarjanje nove strukture potrebno $\mathrm{v}$ prvi vrsti mobilizirati vse lokalne razvojne potenciale in povečati prepoznavnost ter privlačnost posameznega območja za privabljanje kapitala na eni in uspešno trženje produktov na drugi strani.

Iz programa Phare, predvsem programa čezmejnega sodelovanja, ki je bil usmerjen v obmejna območja Slovenije in namenjen predvsem naložbam, ki naj bi omogočile zmanjšanje razlik v razvitosti obmejnih področij z Italijo, Madžarsko in Avstrijo, je Slovenija od leta 1994 prejela preko 37 milijonov evrov. Od tega 18 mio EUR za sodelovanje z Italijo, 14 mio EUR za sodelovanje z Avstrijo in 3 mio EUR za sodelovanje z Madžarsko. Slovenija je v obdobju 1994 - 1999 vložila iz svojih proračunskih sredstev za sodelovanje v vseh čezmejnih programih okrog 22 mio EUR, kar predstavlja skoraj $39 \%$, glede na vrednost celotnega programa, ki znaša 57 mio EUR. Tu gre predvsem za naložbe v infrastrukturo, objekte in okolje (čistilne naprave). Pomemben del gre tudi programu gospodarskega sodelovanja ter projektom v turizmu. Veliko projektov je bilo pomembnih za ohranjanje identitete slovenskega podeželja. V obdobju 1994-1999 je bilo odobrenih več kakor 150 projektov: cestne povezave in obmejna infrastruktura, čistilne naprave, poslovni objekti in tehnološki park, odprte vinske in sadne poti, turistično in kulturno sodelovanje. Posebej uspešen instrument je bil sklad malih projektov, ki je bil namenjen spodbujanju lokalnih iniciativ, ki omogoča pridobivanje izkušenj na področju priprave in vodenja projektov, ki vključuje manjše projekte, namenjene izključno neposrednemu sodelovanju ljudi ob meji, predvsem na področju kulture, športa, glasbe, umetnosti, izobraževanja, srečevanja in podobno. 
Tabela 1: Primer določanja prioritet in programov v program Phare CBC-Interreg SlovenijaAvstrija

Table 1: Setting up priorities and programmes for Phare CBC-Interreg IIIA Slovenia-Austria

\begin{tabular}{|c|c|c|}
\hline $\begin{array}{c}\text { PRIORITETA 1 } \\
\text { Ekonomska } \\
\text { kohezija }\end{array}$ & $\begin{array}{c}\text { PRIORITETA 2 } \\
\text { Človeški viri } \\
\text { in regionalno } \\
\text { sodelovanje }\end{array}$ & $\begin{array}{c}\text { PRIORITETA 3 } \\
\text { Trajnostni } \\
\text { prostorski razvoj }\end{array}$ \\
\hline $\begin{array}{c}\text { PROGRAM 1 } \\
\text { Gospodarski } \\
\text { razvoj }\end{array}$ & $\begin{array}{c}\text { PROGRAM 1 } \\
\text { Razvoj človeških } \\
\text { virov in trg dela }\end{array}$ & $\begin{array}{c}\text { PROGRAM 1 } \\
\text { Prostorski razvoj } \\
\text { in promet }\end{array}$ \\
\hline $\begin{array}{c}\text { PROGRAM 2 } \\
\text { Turizem }\end{array}$ & $\begin{array}{c}\text { PROGRAM 2 } \\
\text { Regionalno } \\
\text { sodelovanje }\end{array}$ & $\begin{array}{c}\text { PROGRAM 2 } \\
\text { Trajnostni razvoj } \\
\text { naravnih virov }\end{array}$ \\
\hline PROGRAM 3 & $\begin{array}{c}\text { PROGRAM 3 } \\
\text { Izobraževanje in } \\
\text { kultura }\end{array}$ & $\begin{array}{c}\text { PROGRAM 3 } \\
\text { Okolje in energija }\end{array}$ \\
\hline
\end{tabular}

\section{I Čezmejno sodelovanje z Italijo}

Ko se je leta 1994 Evropska unija odločila, da razširi program iniciative Interreg oziroma medregionalnega sodelovanja tudi na obmejna območja izven svojih meja, je Vlada Republike Slovenije s Komisijo Evropske unije podpisala memorandum o Programu za čezmejno sodelovanje med Slovenijo in Italijo za leto 1994. V ta namen je bilo Sloveniji odobrenih 4 mio EUR za investicijske projekte s področja mejnih prehodov in obmejne infrastrukture, okolja in kmetijstva.

Novembra 1995 so Vlada Republike Slovenije, Komisija Evropske unije in Vlada Republike Italije podpisale "Skupno izjavo o nameri” o večletnem sodelovanju in tudi skupaj pripravile okvirni dokument tega sodelovanja, pod imenom "Večletni indikativni program za obdobje 1996-1999”, ki skupaj z izjavo o nameri definirata cilje sodelovanja, prioritetna področja, merila za izbor projektov in finančni okvir.

Finančni okvir opredeljuje sredstva po prioritetnih področjih in sicer:

- promet in obmejna infrastruktura: $18 \%$

- $\quad$ okolje: $30 \%$

- $\quad$ gospodarsko sodelovanje (drobno gospodarstvo, kmetijstvo, turizem): $33 \%$

- človeški viri in povezovanje: $10 \%$

- $\quad$ kultura: $4 \%$

- tehnična pomoč: $5 \%$

$\mathrm{S}$ podpisom teh dokumentov je Sloveniji letno zagotovljeno s strani Evropske unije, za sodelovanje z Italijo 3 mio ECU. 


\section{2 Čezmejno sodelovanje z Avstrijo}

Od leta 1995, ko je Avstrija postala članica Evropske unije pa je Komisija Evropske unije razširila in finančno podprla tudi sodelovanje Slovenije v Programu čezmejnega sodelovanja z Avstrijo. Tudi v sodelovanju z Avstrijo so bili podpisani enaki dokumenti kot z Italijo.

Prioritetna področja pa so bila:

- $\quad$ promet in obmejna infrastruktura: $25 \%$

- $\quad$ okolje: $26 \%$

- gospodarsko sodelovanje (drobno gospodarstvo, kmetijstvo, turizem): $40 \%$

- $\quad$ človeški viri, kultura in povezovanje: $3 \%$

- tehnična pomoč: $6 \%$

\subsection{Trilateralno čezmejno sodelovanje z Avstrijo in Madžarsko}

Komisija Evropske unije je konec leta 1995 odprla novo finančno linijo v skupni višini 12,95 mio ECU za Phare program čezmejnega sodelovanja, namenjenega multilateralnemu sodelovanje, ki je omogočal povezovanje obmejnih območij v državi članici z dvema ali več obmejnimi območji v državah kandidatkah. Znotraj tega programa je Slovenija dobila možnost sodelovanja z Avstrijo in Madžarsko in si pridobila za to sodelovanje 1,5 mio ECU. 1,5 mio ECU je Slovenija dobila odobrenih za sodelovanje na tem programu tudi za leto 1996.

\subsection{Bilateralno čezmejno sodelovanje z Madžarsko ali CREDO program}

V letu 1996 je Komisija Evropske unije v okviru Multicountry programa, ki je omogočal čezmejno sodelovanje med Srednje in Vzhodno Evropskimi državami, ki so bile prejemnice pomoči programa Phare CBC. t.i. program CREDO, v okviru katerega so bili podprti predvsem projekti lokalnega značaja.

Med 2000-2002 je bilo za program čezmejnega sodelovanja letno predvidenih 7 milijonov evrov za celotno obmejno območje Slovenije. Po novih usmeritvah za program Phare iz leta 1999 je najmanjša vrednost projekta 2 milijona evrov, zato je bilo med letoma 2000 in 2001 programiranje koncentrirano, za leto 2002 pa je predvidena letna razporeditev sredstev za vse tri meje, kar pomeni en projekt na mejo v višini 2 milijona evrov in Sklad malih projektov.

\section{PRIPRAVA SKUPNIH PROGRAMSKIH OKVIROV PHARE CBCI INTERREG IIIA}

Leta 2000 se je za Slovenijo začelo pristopno obdobje (2000-2006). V tej fazi se je pomoč usmerjala $\mathrm{v}$ krepitev upravno-administrativnih struktur in intenzivne priprave na izvajanje prihodnje strukturne politike. Evropski svet je na zasedanju v Berlinu marca 1999 sprejel sklep, da se pomoč kandidatkam za članstvo poveča in ciljno izvaja s prenovljenim 
programom Phare in dvema novima instrumentoma, ISPA in SAPARD. Slovenija je tako v pristopnem obdobju letno prejela okvirno naslednji obseg sredstev:

\begin{tabular}{|l|r|}
\hline $\begin{array}{l}\text { PHARE: podpira institucionalne reforme in naložbe v t. i. ekonomsko } \\
\text { in socialno kohezijo }\end{array}$ & 25 milijonov evrov* \\
\hline $\begin{array}{l}\text { ISPA: namenjena za večje investicije v prometno infrastrukturo in } \\
\text { okolje }\end{array}$ & $10-21$ milijonov evrov \\
\hline SAPARD: spodbuja kmetijstvo in razvoj podeželja & 6,5 milijonov evrov \\
\hline
\end{tabular}

Novo programsko obdobje 2000-2006 je prineslo nove smernice, ki temeljijo zlasti na socialni in ekonomski koheziji, kar naj bi države kandidatke še bolj poglobljeno uvajalo v strukturno in kohezijsko politiko Evropske unije.

Sosednje države, Italija, Avstrija, Hrvaška in Madžarska, predstavljajo namreč za Slovenijo pomemben regionalni prostor, kamor Slovenija izvaža 30,9 \% svojega celotnega izvoza in od koder uvaža 33,0 \% svojega celotnega uvoza. Italija je naša druga, Hrvaška tretja in Avstrija četrta najpomembnejša zunanjetrgovinska partnerica. Sosednje države so tudi med najpomembnejšimi investitoricami v Slovenijo - na Avstrijo odpade 45,6 \% celotne vrednosti neposrednih tujih investicij v Slovenijo - ter prejemnicami investicij iz Slovenije - na Hrvaško odpade $45,1 \%$ celotne vrednosti slovenskih neposrednih investicij v tujino.

Zakon o spodbujanju skladnega regionalnega razvoja predstavlja zasnovo nove regionalne strukturne politike, povzema evropsko načelo, da se sredstva strukturne pomoči odobrijo le na podlagi razvojnih programov in izvedbenih dokumentov. Pridobivanje razvojnih sredstev iz državnega proračuna in virov predstrukturne pomoči Evropske unije temelji tako na načelu programiranega usmerjanja sredstev, kar pomeni, da bo državna pomoč in sofinanciranje razvojnih programov odobrena le za konkretne razvojne projekte, ki morajo biti obvezno usklajeni $\mathrm{v}$ regionalnem razvojnem programu. Za Slovenijo je bilo pomembno načelo dodatnosti pomoči, ki zahteva, da se pri razvojni projekti financiranih iz državnega proračuna zagotavlja sofinanciranje iz drugih javnih in zasebnih virov v ustreznih deležih.

Zaradi velike razdrobljenosti slovenskega ozemlja na majhne občine s težnjo še nadaljnje delitve in ob odsotnosti regionalne ravni prevladujeta na področju razvojnega odločanja državna raven in centralizirano odločanje. Pretirana centralizacija in zavrte lokalne pobude so ena od pomembnejših ovir za hitrejši gospodarski razvoj v državi in razlog za poglabljanje medregionalnih razlik. Zato je bilo v zakonu o spodbujanju skladnega regionalnega razvoja, sprejetem v letu 1999, dan poseben poudarek načelu partnerstva, ki je predvidelo nastanek novih organizacijskih struktur na regionalni ravni - regionalnih razvojnih agencij, ki naj bi bile sposobne sprejemati in polno izkoristiti nove usmeritve in instrumente regionalne politike. Ustanovitev in usposobitev regionalnih razvojnih agencij je bila spodbujana s strani države brez neposredne državne prisile. Občinam je bila prepuščena odgovornost, da oblikujejo najprimernejšo obliko strokovne organiziranosti za oblikovanje in izvajanje razvojne politike na regionalni ravni.

Spodbude, pomembne za regionalni razvoj so bile usmerjene v naslednja področja; podjetniška vlaganja, razvoj infrastrukture, tekoče poslovanje gospodarskih družb, restrukturiranje, usposabljanje kadrov za izvajanje regionalne strukturne politike, dodeljevale pa se 
bodo v obliki subvencij, ugodnih posojil, poroštev, davčnih oprostitev in olajšav, kot so določene $\mathrm{z}$ davčnimi predpisi, kapitalskih vložkov, prenosa državnega premoženja $\mathrm{v}$ upravljanje državnim skladom, $\mathrm{z}$ namenom vlaganja tega premoženja $\mathrm{v}$ regionalne razvojne projekte, podeljevanjem statusa ekonomskega območja in podeljevanjem statusa območij za pospeševanje zaposlovanja.

Za Slovenijo je bilo v pristopnem obdobju pomembno tudi evropsko načelo dodatnosti pomoči, ki zahteva, da se iz državnega proračuna ter iz drugih javnih in privatnih sredstev zagotavlja ustrezni del sredstev za sofinanciranje razvojnih projektov (načelo sofinanciranja ali dodatnosti pomoči). To načelo je bilo oblikovano na način, ki zahteva zagotovitev sredstev za sofinanciranje projektov iz privatnih in lokalnih javnih virov, če del sredstev zagotavlja državni proračun.

Skupni programski dokument za vsako od obmejnih območij zagotavlja naslednje vire: Slovenija-Italija (Phare CBC/INTERREG IIIA), letna alokacija 2,5 mio EUR SlovenijaAvstrija (Phare CBC/INTERREG IIIA), letna alokacija 2,5 mio EUR Slovenija- Madžarska (Phare CBC/Phare CBC), letna alokacija 2 mio EUR.

\section{GLAVNI PROBLEMI OBMEJNEGA SODELOVANJA}

Kljub temu, dajebilo sodelovanjezsosednjimi državamiv obeh obdobjih, predpristopnem kot tudi pristopnem zelo dobro, ostaja eden glavnih problemov našega čezmejnega sodelovanja še vedno dejstvo, da je naš sedanji upravni sistem neprimerljiv s sosednjimi državami. Zaradi odsotnosti regionalnega nivoja moramo zato vložiti več napora za obvladovanje čezmejnega sodelovanja in vzdrževanja nivoja kot ga imajo sosednje države. To pomeni, da na regionalni oziroma lokalni ravni, nimamo organizirane neke javne infrastrukture, ki bi celovito nudila podporo pri vzpostavljanju ali širjenju stikov in sodelovanja. Premalo je vzpostavljenih struktur, ki bi motivirale, usmerjale in podpirale izvajanje skupnih projektov. Odprto je tudi vprašanje zagotavljanja lokalnih virov za podporo izvajanju iniciativ. Do sedaj oblikovane skupne strategije za izvajanje projektov na obeh straneh, ki bi zagotavljale skladnost ter predvsem komplementarnost razvoja, so pogosto enostranske in potrebne prenove. Odsotnost organizirane animacijske aktivnosti, ki bi predstavila priložnosti za skupen razvoj, vodi na nekaterih področjih do nerazumevanja in tudi odporov zaradi strahu pred konkurenco.

\section{SKLEP}

Med glavnimi vplivi Phare programa čezmejnega sodelovanja v obdobju 1994-2004 prepoznavamo:

- $\quad$ povečano ekonomsko rast obmejnih regij, še posebej na področju razvoja malega gospodarstva in kooperacij,

- $\quad$ povečano konkurenčnost na področju turizma, skupnem trženju in promociji,

- povečano vitalnost ruralnih območij na področju intenziviranja kmetijske proizvodnje v skladu z naravnimi danostmi, uvajanje novih tržno zanimivih proizvodenj, izboljšanim trženjem kmetijskih proizvodov, 
- $\quad$ izboljšano prometno infrastrukturo s povečanjem dostopnosti in prehodnosti,

- $\quad$ vlaganja v razvoj človeških potencialov ter izboljšanje možnosti in kakovosti izobraževanja kot tudi oblikovanje skupnih programov za reševanje problemov nezaposlenosti,

- varovanje naravnih potencialov z odpravljanjem onesnaževanja ter naravnih danosti v skladu z načeli trajnostnega razvoja,

- $\quad$ povečano sodelovanje "ljudje ljudem” na področjih kulture, športa, glasbe, umetnosti, zdravstva, izobraževanja.

Navedeni vplivi so dokaj enakomerno zastopani v celotnem obmejnem območju, ob vseh mejah Republike Slovenije z Italijo, Avstrijo in Madžarsko. Pričakujemo, da bodo sorodni procesi vidni tudi ob slovensko-hrvaški državni meji, kjer že potekajo predpristopni programi, po vsebini podobni predhodno opisanim.

\section{Viri in literatura}

Bufon, M. (1995): Prostor, meje in ljudje, Slovenski raziskovalni inštitut, Trst, 439 str.

Pečar, J. (2002): Regionalni vidiki razvoja Slovenije, Delovni zvezki št.7, Urad za makroekonomske analize in razvoj, Ljubljana

Piry, I. (1999), Regional development policy in Republic of Slovenia, Gleichwertige Lebensbedingungen in Mittelosteuropa/Akademie für Raumforschung und Landesplannung. - Hannover, ARL

Piry, I. (2000), The institutional framework of regional development policies in Slovenia, v Implementing structural funds/edited by Jan Maarten de Vet, Luc Boot, Menno Hollanders. - Rotterdam : The Netherlands Economic Institute

Piry, I., (2004), Slovenija v Evropski uniji - geografske razsežnosti članstva v EU, 19. zborovanje slovenskih geografov, Velenje

European Commission, DG XVI (1999) The New Programming period 2000-2006: methodological working papers, Vademecum for Structural Funds Plans and Programming Documents

Medmrežje:http://ec.europa.eu/regional_policy/interreg3/doc/docu_en.htm, Dokumenti o pobudi Interreg III EU

EU-Slovenija pododbor št. 7 za regionalni razvoj, zaposlovanje in socialno politiko, letna poročila 2000, 2001, 2002, interno gradivo, Služba Vlade RS za evropske zadeve 


\title{
INFLUENCE OF EU PRE-ACCESSION PROGRAMMES ON REGIONAL DEVELOPMENT OF BORDER AREAS OF SLOVENIA IN PERIOD I994-2004
}

\begin{abstract}
Summary
Regional co-operation in Slovenia is in a way bound to the process of it's inclusion into European union, especially with the start up of preaccession assistance programmes to candidate countries like Phare CBC in 1995 in the border areas between Slovenia and Austria as well as Italy, which started introducing preparation of strategic development documents as a basis for future co-ordination of development projects in different areas of common interest. Phare programme co-financed preparation of the White paper on Regional Development in 1999 , which formed the core of present Strategy of Regional Development of Slovenia, adopted in 2001. Assistance of Phare Special Preparatory Programme was aimed at institutional capacity building that would enable efficient institutional setup for implementation of structural and cohesion policy . The largest share of this Phare funding has been for institution building at all levels and the second largest share for infrastructure, environment, transport and energy support and education and training. During the first period of EU accession process Slovenia couldn't pay much more attention to the regional aspect of development programmes.

Slovenia benefited from pre-accession programmes, especially Phare CBC and ESC in acquiring knowledge and re-inventing the programme approach, introducing partnership relationship between different stakeholders, strengthening public procurement procedures and defining the roles of different institutions. Specific experience have been encountered in establishing "network RDAs" in the areas where strong local initiatives existed.

Slovenia has been for quite a long time implementing specific kind of regional policy, based on a concept of polycentric urban development, that would provide for balanced regional development of all areas in the country. The differences between the most and the least developed region in the country are stabilised at 1:1,9 ratio in terms of BDP/ppp. Due to the specific geographical characteristics ( predominantly mountainous and karst areas, extensive border areas facing with peripheral position) territorial division of the country for regional policy purposes is based on NUTS 3 level, enabling specific issues to be dealt with appropriate measures. Programs included infrastructure projects, like reconstruction of border crossings and improvements of local road connections to enable easier cross-border traffic, construction of waste water treatment plants for sanation of environmental problem areas along the border.

An important factor in regional disparities (contributing to the underlying philosophy of Slovenian regional policy until recently) is the country's demography. The Slovenian population is unevenly distributed, with over 75 percent of the country's population living in only a third of its territory. The average population density in these areas is 215 inhabitants per $\mathrm{km} 2$ and the population concentration continues to rise. Conversely, areas with stagnating population levels comprise 26 percent of the territory and 12 percent of the population, with an average population density of only 45 inhabitants per $\mathrm{km}^{2}$. Depopulating areas tend to be the peripheral and agricultural areas (eg. Pomurska, Posavska, Goriska and Kraska) as well
\end{abstract}


as the Zasavska region which was a former industrial and coal-mining area. The settlement structure is dispersed, with only two towns having a population exceeding 100,000 inhabitants (Ljubljana and Maribor). The population is ageing and low birth rates and migration trends mean that concerns exist about whether there will be sufficient demographic reserves to meet the gap in the active population in the future.

The Government adopted the first Law on Balanced Regional Development in 1999 which promotes partnership between the state, local self government and economy in establishment of regional development councils, assisted by RDAs as secretariats and gives push to private public partnership in implementation of development projects

According to the experiences gained in past periods of regional policy in Slovenia, supported by EU Phare programmes pf cross-border co-operation there should exist a setup of policy instruments, which could promote balanced regional development according to specific territorial potentials, increase assistance to cross border co-operation programs and include facts like nature preservation areas and bio-diversity as cornerstones of sustainable development. 